\title{
Urgent action to fight hepatitis $C$ in people who inject drugs in Europe
}

\author{
John F. Dillon ${ }^{*}$, Jeffrey V. Lazarus ${ }^{2}$ and Homie A. Razavi ${ }^{3}$
}

\begin{abstract}
Hepatitis C virus (HCV) infection is a leading cause of liver cirrhosis and liver cancer, is curable in most people. Injecting drug use currently accounts for $80 \%$ of new HCV infections with a known transmission route in the European Union (EU). HCV has generally received little attention from the public or policymakers in the EU, with major gaps in national-level strategies, action plans, guidelines and the evidence base. Specifically, people who inject drugs (PWID) are often excluded from treatment owing to various patient, healthcare provider and health system factors. All policymakers responsible for health services in EU countries should ensure that prevention, treatment, care and support interventions addressing HCV in PWID are developed and implemented. According to current best practice, PWID should have access to comprehensive, evidence-based multiprofessional harm reduction (especially opioid substitution therapy and clean needles and syringes) and support/care services based in the community and modified with community involvement to accommodate this hard-to-reach population. Other recommended components of care include vaccination against hepatitis B and other infections; peer support interventions; HIV testing, prevention and treatment; drug and alcohol services; psychological care as needed; and social support services. HCV testing should be performed regularly in PWID to identify infected persons and engage them in care. HCV-infected PWID should be considered for antiviral treatment (based on an individualised assessment and delivered within multidisciplinary care/support programmes) both to cure infected individuals and prevent onward transmission. Modelling data suggest that the HCV disease burden can only be cut substantially if antiviral treatment is scaled up together with prevention programmes. Measures should be taken to reduce stigma and discrimination against PWID at the provider and institutional levels.

In conclusion, strategic action at the policy level is urgently needed to increase access to HCV prevention, testing and treatment among PWID, the group at highest risk of HCV infection. Such action has the potential to substantially reduce the number of infected persons, along with the disease burden and related care costs.
\end{abstract}

Keywords: Antiviral therapy, Harm reduction, Hepatitis C, People who inject drugs, Risk reduction behaviour

\section{Background}

According to the World Health Organization (WHO), 14 million people in the European Region are chronically infected with hepatitis $\mathrm{C}$ virus (HCV), a blood-borne infection of the liver [1]. Another recent study has estimated that there are 3.6 million people with viraemic $\mathrm{HCV}$ infections in the EU [2]. HCV is a leading cause of liver cirrhosis and liver cancer and around 70,500 infected people die each year in the European Union as a result of these complications [3]. Without action, the burden of $\mathrm{HCV}$ disease

\footnotetext{
* Correspondence: j.f.dillon@dundee.ac.uk

${ }^{1}$ Division of Molecular and Clinical Medicine, School of Medicine, University of Dundee, Ninewells Hospital, Dundee, UK

Full list of author information is available at the end of the article
}

is expected to rise in the coming years owing to the ageing of the infected population, ongoing new infections and low levels of treatment uptake [4-6]. For example, the number of HCV-related cirrhosis cases in England is expected to increase by $50 \%$ by 2030 , while $\mathrm{HCV}$-related deaths will almost double [4].

Injecting drug use currently accounts for $80 \%$ of new $\mathrm{HCV}$ infections in the European Union with a known transmission route [7]. Globally, two out of three people who inject drugs (PWID) have HCV infection [8], with rates in European Union countries varying between $14 \%$ and $84 \%$ [9]. However, HCV remains a hidden epidemic. A pooled analysis of data from studies in Denmark, France, Poland, Spain and the United Kingdom estimated 
that a median of $49 \%$ of $\mathrm{HCV}$-infected PWID were undiagnosed (range: 24-76 \%) [10]. HCV is transmitted more easily than HIV and globally there are more than three times as many PWID infected with HCV than with HIV [8]. When formulating strategies to address the problem of $\mathrm{HCV}$ infection, especially if considering treatment as prevention strategies, it is important to differentiate between individuals who are currently active drug injectors and those who are former injectors. In addition, among active injecting drug users, it is important to distinguish between those who share injecting equipment and those who do not. HCV is spread between PWID primarily by the sharing of injection equipment and thus the vast majority of new infections occurs in active injectors who share.

The window of opportunity for HCV prevention is narrow, as infection is likely to occur soon after initiation of injection drug use. The time to infection is shortest among individuals with many contacts within their network of drug users and among those who inject most frequently [11]. Furthermore, the incidence of infection is highest among individuals who do not utilise existing harm reduction services such as opioid substitution therapy (OST) and sterile needle and syringe programmes (NSP). HCV in PWID is preventable and curable, and therefore efforts to reduce the incidence and transmission of $\mathrm{HCV}$ infection must aim to increase access to testing, risk reduction and treatment in this population, with a strong focus on active injectors. Treatment with antiviral medicines is as effective in PWID as in non-drug users [12], and guidelines published by international and European organisations identify the prevention and treatment of $\mathrm{HCV}$ among PWID as major components of protecting the public from blood-borne viruses [13-16].

The European Commission recognises PWID as a key target group in its ongoing activities to address bloodborne viruses, and in October 2015 it launched a threeyear Joint Action that engaged representatives of 18 Member States in efforts to intensify the response to HIV and viral hepatitis among PWID [17] and followed this up with a second Joint Action on these issues in 2016. However, considering the extent of the public health threat, HCV has generally received little attention from the public or policymakers in the European Union, with major gaps in international and national-level strategies, action plans, guidelines and in the evidence base more generally [10, 18-20]. This paper discusses barriers to improving $\mathrm{HCV}$ care for PWID and current best practices in HCV prevention, diagnosis and treatment in PWID in the context of recent data and relevant policy initiatives. It concludes by making policy recommendations to address unmet needs in PWID and thereby strengthen the response to $\mathrm{HCV}$ in the European Union.

\section{Barriers to improving HCV care for PWID}

A recent study of the EU countries found an overall diagnosis rate for $\mathrm{HCV}$ infection of $33 \%$ and a treatment rate of $3.7 \%$ [2]. Median treatment rates specifically among diagnosed PWID have been estimated at around $10-30 \%[10,21]$, but this masks wide variation within and between countries and of course many PWID are not even diagnosed. A study of seven sites in the UK found that treatment rates among PWID varied from $<5$ to $>25$ per 1000 PWID [22]. Of course, many more PWID are not even diagnosed. Access to prevention, testing and treatment is even more limited in prisons than in the community, despite high rates of HCV in the prison population internationally $[23,24]$ as well as legal and human rights obligations for governments to provide health care to prison inmates.

A fundamental dilemma is that PWID, in whom HCV infection is most common and in whom treatment to prevent onward transmission is particularly important, are generally difficult to engage in formal healthcare services. PWID are often wrongly excluded from treatment, and uptake rates are low even where treatment is offered. The main barriers to PWID accessing care for HCV include [21, 25-28]:

- Patient-related factors, such as lack of awareness of diagnosis or HCV status; limited knowledge or negative perceptions of $\mathrm{HCV}$ and how it is treated; low levels of health literacy; negative relations with the healthcare system, including fear of or experience of stigmatization; social, medical and psychiatric co-morbidities; lack of insurance; low socioeconomic status; homelessness or unstable housing; and factors relating to migrant status or ethnic/cultural minority status;

- Healthcare provider-related factors, such as limited expertise in HCV care for PWID; misperceptions that treatment is less effective or is associated with high re-infection rates in PWID versus non-PWID groups; and discrimination or stigmatization toward PWID;

- System-related and institutional factors, such as lack of infrastructure or treatment settings adapted or conveniently located for PWID; lack of coordination or collaboration among providers of different services; lack of suitable training programmes; high treatment fees; criminalisation of PWID; and a lack of validated, shared, systematic national data on the health and economic impact of $\mathrm{HCV}$ to inform service investment and planning.

Programmes for $\mathrm{HCV}$ treatment as prevention will only work if high levels of coverage and adherence are 
achieved and maintained. In light of the known barriers, $\mathrm{HCV}$ services need to be modified to effectively deliver harm reduction interventions and antiviral treatment to hard-to-reach populations. Survey data suggest that the majority of PWID may be willing to receive treatment for HCV if it is available to them [29]. However, whether individuals undertake and adhere to treatment in practice will depend on how they prioritise this option in relation to various competing priorities and challenges [26]. Some individuals may need particular encouragement, making advocacy and peer support important features of efforts to scale up treatment.

The question of whether further measures to incentivise PWID into care should be employed, and what form these should take, has received little attention to date. In conventional health services, patients with symptoms are motivated to seek health care as a means of obtaining relief from the symptoms. Similarly, patients are motivated to participate in $\mathrm{HCV}$ testing programmes because of their recognition that a diagnosis can lead to the timely initiation of treatment, reducing the risk of complications from the disease. In both cases, health-seeking behaviour is rewarded. In the PWID population, these mechanisms may be much less powerful. PWID often have quite nihilistic views of the future [30,31], and as $\mathrm{HCV}$ is frequently asymptomatic, there are few drivers for treatment-seeking behaviour. This is compounded further if early treatment is perceived to principally benefit society (in terms of prevention of transmission, as discussed below) rather than infected individuals. Such perceptions may result from the asymptomatic nature of early infection or a lack of knowledge or concern about the long-term consequences of chronic $\mathrm{HCV}$ infection among some PWID. Additionally, for treatment as prevention strategies to work, the uptake of treatment needs to be high, as a small number of individuals at key points in networks could reinfect many people who have been cured. Therefore, incentives or contingency management programs should be considered. Assessed in a variety of diseases and populations by the National Institute for Health and Care Excellence in England and Wales and found to be cost-effective and acceptable [32], these should be considered a key component of motivating active PWID populations into treatment.

Crucially, many countries lack national evidence-based best practice programmes such as the one implemented and evaluated in Scotland [33]. In 2006, the Scottish Government launched its Hepatitis C Action Plan for the purposes of improving services to prevent transmission of $\mathrm{HCV}$ infection (particularly among PWID), identifying those infected, and ensuring that those infected receive optimal treatment, care and support [33]. The comprehensive plan was based on evidence from national monitoring systems and models showing the potential benefit of scaling up therapy and the mounting cost of inaction, and was informed by stakeholder consultations. It was implemented by national and local multidisciplinary, multi-agency networks, coordinated by Health Protection Scotland and supported by substantial government investment. Achievements include an increase of approximately $50 \%$ in the proportion of the infected population diagnosed ( $38 \%$ to $55 \%$ ); a nearly three-fold increase in the annual number of PWID initiating therapy, and a reversal of the upward trend in the overall number of people living with chronic $\mathrm{HCV}$ infection [33].

\section{Prevention, harm reduction and testing}

There is currently no vaccine against HCV. However, $\mathrm{HCV}$ infection among PWID can be greatly reduced using a combination of prevention strategies [13, 34]. PWID should have access to comprehensive harm reduction and support/care services. These services should also be based in the community, to facilitate access by PWID and to aid service expansion. Guidelines by WHO [13], the Joint United Nations Programme on HIV/AIDS [35], the European Centre for Disease Prevention and Control (ECDC)/European Monitoring Centre for Drugs and Drug Addiction [14] and other experts [15, 16, 36] all recommend packages of services that include the following elements (Fig. 1).

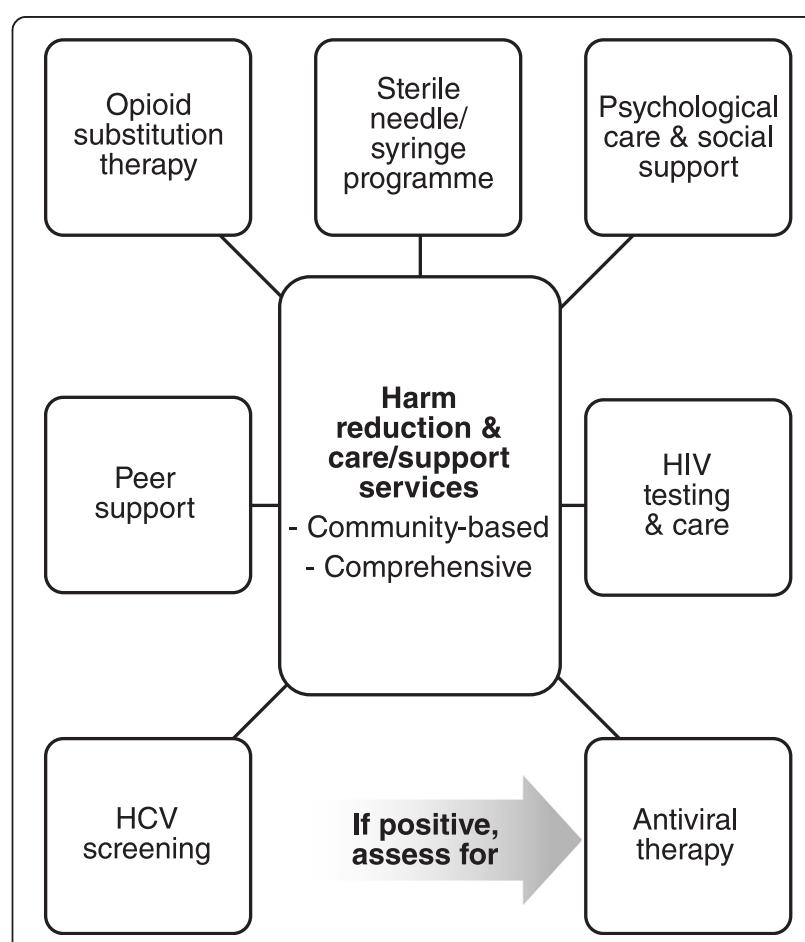

Fig. 1 Components of comprehensive hepatitis $\mathrm{C}$ virus (HCV) care services to which people who inject drugs should have access 


\section{Prevention and harm reduction}

PWID should have easy access to harm reduction services, two key components of which are OST and NSP [13, 14, 35]. As well as reducing $\mathrm{HCV}$ risk behaviour and transmission through injecting drug use, these interventions can serve as a platform to promote $\mathrm{HCV}$ care. While harm reduction services are often grouped together, it is important to differentiate them and their potential utility in efforts to combat HCV. NSP programmes by definition are focussed on those still injecting and aim to make the act of injecting safer. Such services greatly reduce the rate of transmission. Therefore, it is logical to make this group the focus of treatment-as-prevention strategies. OST services take many forms across countries and regions depending on local legal requirements and regulations; some are very open to unstable and active injectors while others require PWID to modify their drug use to varying degrees as a condition for initiating or continuing OST. The design of the OST service model has considerable implications for the efficacy of OST as a prevention tool for $\mathrm{HCV}$, with the only likely prevention benefit being seen in the context of low-threshold early access leading to reduced injecting frequency. The use of peer support interventions within these services is recommended [13, 14, 35]. Various models of peer support exist [37], including those that promote education, engagement in services, and treatment uptake and assessment [37-40]. HIV testing, prevention and care should be provided in concert. Available data suggest that the prevalence of $\mathrm{HIV} / \mathrm{HCV}$ co-infection ranges widely across Europe, depending on the prevalence of HIV [10]. Other recommended components of care for PWID include: vaccination against other infections (e.g. hepatitis A and B, tetanus), psychological care for selected cases, and social support services [13-16, 35, 41].

The 2013-2016 European Commission Action Plan on Drugs charges Member States with ensuring that treatment and outreach services incorporate greater access to risk and harm reduction options to reduce the consequences of drug use including transmission of bloodborne viruses [42]. There are examples of good practice underway in Europe [33, 43], but the unmet need is still high $[44,45]$.

\section{Testing}

Many individuals with chronic HCV infection are diagnosed after being infected for many years and enter care only when they develop clinical symptoms, despite having been engaged by the healthcare system earlier [46]. Late diagnosis of $\mathrm{HCV}$ is associated with worse outcomes [46] and with the risk of onward transmission. Many opportunities for timely diagnosis of HCV infection are missed, especially in PWID populations. Active testing of PWID who are current injectors is rarely undertaken. It is argued that treatment of such patients is too difficult, too expensive and the risk of re-infection too high, although the developing evidence base clearly shows that this is not the case. Additionally, the diagnosis of HCV may change behaviour in the short term or identify patients who could be followed up for treatment in the future before presenting with liver failure. Recently, the European Association for the Study of the Liver and the HIV in Europe initiative developed a new consensus definition of late presentation for viral hepatitis [47]. This is an important performance indicator of success for programmes aiming to improve the identification and management of viral hepatitis.

HCV testing should be performed regularly in PWID to identify infected persons and engage them in care and treatment [13-16]. HCV antibody testing is recommended, and if the result is positive, a more sensitive HCV RNA test should be performed to determine whether or not there is current infection $[13,16]$. Targeted HCV testing linked to treatment increases diagnosis rates and treatment uptake [48] and is a cost-effective way to reduce the disease burden [49]. New types of rapid and point-of-care HCV tests (e.g. dried blood spot tests) can help to increase the number of tested individuals, especially in hard-to-reach groups $[13,50]$. However, according to a 2013 survey, only six of 44 countries in the European Region provided hepatitis B and $C$ virus testing to PWID at no charge [20].

\section{Antiviral treatment: individual benefit and transmission prevention}

$\mathrm{HCV}$ antiviral treatment aims to cure, or eradicate, $\mathrm{HCV}$ infection in individuals, thereby preventing its complications and death [15]. HCV treatments are assessed according to the sustained virological response rate (SVR), defined as the proportion of patients with undetectable HCV RNA measured after 12 or 24 weeks according to defined methods. Patients who achieve an SVR remain free of the virus in $99 \%$ of cases and hence are considered cured $[15,51]$. An SVR has been associated with significantly reduced risks of 10-year all-cause mortality, and liver-related mortality or transplantation, among HCVinfected individuals with advanced hepatic fibrosis [52].

The introduction of direct-acting antiviral (DAA) therapies in recent years has revolutionised the treatment of HCV. Previously, pegylated interferon/ribavirin (peg-IFN/ RBV) regimens were only moderately effective (depending on the HCV genotype), required IFN injections and variable treatment durations up to 48 or even 72 weeks, and were associated with significant toxicities. New all-oral IFN-free DAA regimens, given for 8-24 weeks, are much more effective (achieving SVR rates of $\geq 90 \%$ in clinical trials), and are generally well tolerated $[13,15,53]$. It can be extrapolated that the much higher SVRs achieved will 
still be associated with the reduced liver and all-cause mortality seen with interferon-based regimens.

Currently, treatment priority is based on fibrosis stage, risk of progression to more advanced disease, presence of extrahepatic manifestations of infection and cirrhosis. It should also take into account the risk of transmission [15]. European and international guidelines recommend that all patients with chronic HCV - including PWID should be considered for antiviral treatment based on an individualised assessment [13-16, 35]. According to a systematic review of studies, the effectiveness of pegIFN/RBV treatment among PWID who are eligible and committed to starting HCV treatment (including active injectors) is similar to that in non-drug users, with high levels of adherence, low rates of treatment discontinuation, and a low rate of reinfection among PWID [12]. These findings support current treatment recommendations and refute misperceptions about poor effectiveness and high rates of re-infection in PWID that can lead to their exclusion from treatment. Indeed, PWID are among the groups that should be prioritised for treatment, regardless of fibrosis stage or extra-hepatic manifestations, in view of their risk of transmitting HCV [15]. Patients who are co-infected with HCV and HIV should also be prioritised for HCV treatment [15]. Importantly, HCV treatment for PWID should be delivered within multidisciplinary care/support programmes that include harm reduction and support services [13-16, 35], including measures to limit alcohol intake and to address obesity, smoking and drug usage.

Curing HCV infection not only benefits infected individuals, but also has the potential to prevent onward viral transmission and hence to reduce the disease burden at the population level [13]. The impact of treatment on $\mathrm{HCV}$ prevalence depends on its effectiveness and on the levels of treatment uptake. Modelling studies in various countries consistently suggest that current levels of treatment using conventional peg-IFN/RBV regimens are unlikely to significantly reduce or even stabilise the disease burden over the next 10 to 15 years [4-6, 54]. According to models, the HCV disease burden can only be cut substantially if antiviral treatment is scaled up together with prevention programmes [22, 54-60]. For example, using dynamic modelling, researchers in the United Kingdom projected that a $50 \%$ reduction in the prevalence of chronic HCV in PWID (from a baseline of $20 \%, 40 \%$ or $60 \%$ ) could be achieved within 10 years by combining OST, NSP and antiviral treatment. A halving of the prevalence was made more achievable (i.e. fewer treatments were needed) if DAAs were used instead of pegIFN/RBV, and also if harm reduction were scaled up [55]. Further modelling, based on real-world data on treatment rates and outcomes from 538 PWID in seven centres in the United Kingdom, suggested that the introduction of
DAA therapies combined with the scaling up of treatment to rates already achieved in some centres - to 26 per 1000 PWID - could allow all seven sites to achieve at least a $15 \%$ absolute reduction in HCV prevalence after 10 years, with prevalence more than halved in three sites [22]. In Scotland, doubling treatment uptake and prioritising PWID was projected to reduce incident infection to negligible levels $(<50$ cases per year) by 2025 and to stabilise rates of severe liver morbidity by 2028 [61]. Targeting those with moderate/advanced fibrosis would stabilise severe liver morbidity five years earlier, but would be significantly less effective in reducing new infections. In Sweden, modelling suggests that doubling the number of DAA treatments overall would bring about $65-70 \%$ reductions in both the incidence of hepatocellular cancer and liverrelated deaths by 2030 [59]. Targeting only patients with advanced fibrosis would only stabilise the incidence of serious complications with minimal impact on the total number of $\mathrm{HCV}$ infections. Internationally, other analyses suggest that a $90 \%$ reduction in total $\mathrm{HCV}$ infections and/or disease burden within 15 years is feasible in most countries studied, provided there is upscaling of testing, harm reduction and efficacious treatment $[5,57]$.

Antiviral treatment among PWID, in combination with harm reduction services, is therefore a critical component of primary prevention of $\mathrm{HCV}$. Despite implementation challenges, treatment uptake rates of $20-22 \%$ have already been reported in dedicated services linking OST and community hepatitis care [22, 62-64]. Furthermore, experience from Scotland shows that a scale-up of antiviral therapy can be achieved without compromising SVR rates, including among PWIDs [65].

The cost of DAA treatments is a barrier to their wide usage in HCV management strategies in most European Union countries. However, PWID were not widely treated even during the previous era of lower cost therapies, underlining the point that particular barriers such as discrimination exist for this group. Economic models indicate that $\mathrm{HCV}$ treatment using DAAs is cost-effective owing to a reduction in the costs of HCV-related complications [66-69]. Few studies have assessed the costeffectiveness of antiviral treatment specifically for PWID (Table 1). Modelling data from Australia and the United Kingdom suggest that treating active or former PWID with peg-IFN/RBV at mild stages of $\mathrm{HCV}$ is cost-effective compared with no antiviral treatment, resulting in incremental cost-effectiveness ratios (ICER, measured as cost per quality adjusted life-years [QALY]) below standard local thresholds for cost-effectiveness [70, 71]. The Australian study and the UK study both took into account the costs of disease progression, together with deleterious aspects such as reinfection, but only one also took into account the prevention effects of treatment on transmission [70]. 
Table 1 Studies modelling the cost-effectiveness of antiviral therapy for hepatitis C virus infection in people who inject drugs (PWID)

\begin{tabular}{|c|c|c|c|c|}
\hline Reference & Country/setting & Design & Intervention and population & Cost impact \\
\hline \multicolumn{5}{|l|}{ PegIFN/RBV therapy } \\
\hline \multirow[t]{5}{*}{ Martin et al. 2012 [70] } & \multirow[t]{5}{*}{ United Kingdom } & $\begin{array}{l}\text { Dynamic disease progression and } \\
\text { transmission model }\end{array}$ & $\begin{array}{l}\text { pegIFN/RBV at mild stage vs no treatment } \\
\text { (best supportive care) in: }\end{array}$ & $\begin{array}{l}\text { ICER for treating current PWID vs no treatment, } \\
\text { according to baseline chronic HCV prevalence: }\end{array}$ \\
\hline & & Probablistic cost-utility analysis & Current PWID & $20 \%$ prevalence: ICER treat PWID vs no treatment $=£ 521 /$ QALY \\
\hline & & \multirow[t]{3}{*}{ Direct medical costs (2010 prices) } & Non/ex PWID & $40 \%$ prevalence: ICER vs no treatment $=£ 2539 /$ QALY \\
\hline & & & \multirow[t]{2}{*}{$N=1000$ individuals } & $60 \%$ prevalence: ICER $=£ 7675^{\mathrm{a}} / \mathrm{QALY}$ \\
\hline & & & & $\begin{array}{l}\text { Treatment of non/ex-PWID dominant at } 60 \% \\
\text { prevalence; ICER £6803/QALY vs no treatment }\end{array}$ \\
\hline \multirow[t]{5}{*}{ Visconti et al. 2013 [71] } & \multirow[t]{5}{*}{ Australia } & Markov decision-analytic model & $\begin{array}{l}\text { pegIFN/RBV at mild (F0/1) stage vs } \\
\text { no treatment (best supportive care) in: }\end{array}$ & Current PWID: \$AUS 7941/QALY \\
\hline & & \multirow[t]{4}{*}{ Direct medical costs (2011 prices) } & Current PWID & Former PWID: \$AUS 5808/QALY \\
\hline & & & Former PWID & Non-injectors: \$AUS 3985/QALY \\
\hline & & & Non-injectors & \multirow{2}{*}{$\begin{array}{l}\text { Treatment at mild stage dominated treatment at later } \\
\text { stages for all cohorts }\end{array}$} \\
\hline & & & $N=1000$ individuals & \\
\hline \multicolumn{5}{|l|}{ DAA therapy } \\
\hline \multirow[t]{4}{*}{ Bennett et al. 2015 [58] } & \multirow[t]{4}{*}{ United Kingdom } & \multirow[t]{3}{*}{$\begin{array}{l}\text { Dynamic model of disease progression, } \\
\text { transmission and treatment }\end{array}$} & $\begin{array}{l}\text { Uptake increased to } 250 \text { per } \\
1000 \text { PWID of: }\end{array}$ & $2015-2027$ \\
\hline & & & Current treatment & Current treatment: $£ 23.4$ million saved ( $£ 5.4$ after discounting) \\
\hline & & & New DAA (SVR90\%) & SVR90\%: £36.3 million saved (£8.4 million after discounting) \\
\hline & & $\begin{array}{l}\text { Lifetime complication rates, costs of } \\
\text { complications }\end{array}$ & $N=4240$ individuals & \\
\hline \multirow[t]{4}{*}{ Hellard et al. 2015 [72] } & \multirow[t]{4}{*}{ Australia } & \multirow{2}{*}{$\begin{array}{l}\text { Closed compartmental model of } \\
\text { disease progression and treatment }\end{array}$} & IFN-free DAA at & Late treatment vs no treatment: \$AUS5078 \\
\hline & & & Early stage (from Fo) & \multirow[t]{3}{*}{ Early treatment vs late treatment: $\$ A \cup S 17,090$} \\
\hline & & Fixed rate of re-infection & Late-stage (from F2/3) & \\
\hline & & Direct healthcare costs (2014 prices) & $\mathrm{N}=1000$ individuals & \\
\hline \multirow[t]{5}{*}{ Scott et al. 2016 [73] } & \multirow[t]{5}{*}{ Australia } & \multirow[t]{5}{*}{$\begin{array}{l}\text { Open compartmental model of } \\
\text { progression, transmission and treatment }\end{array}$} & \multirow{5}{*}{$\begin{array}{l}\text { DAA treatment scale up necessary } \\
\text { to achieve WHO goals of } 65 \% \\
\text { reduction in HCV-related deaths } \\
\text { and } 80 \% \text { reduction in HCV } \\
\text { incidence by } 2030 \text { via two scenarios } \\
\text { if DAA treatment for IDU-acquired } \\
\text { HCV prioritised to: Patients with } \\
\text { advanced liver disease }(F \geq 3) \text { or } \\
\text { Current PWID }\end{array}$} & $\begin{array}{l}\text { Prioritising advanced liver disease: Mortality target required } 5662 \\
\text { ( } 95 \% \text { CI 5202-6901) courses/year (30/1000 IDU-acquired infections) }\end{array}$ \\
\hline & & & & Prioritising PWID: \\
\hline & & & & $\begin{array}{l}\text { Incidence and mortality targets achieved with } 4725 \\
\text { ( } 95 \% \text { Cl 3278-8420) courses per year (59/1000 PWID) }\end{array}$ \\
\hline & & & & $\begin{array}{l}\text { Additional } 5564 \text { (1959-6917) treatments/year (30/1000 IDU-acquired } \\
\text { infections) required for } 5 \text { years for patients with advanced liver disease } \\
\text { to avoid excess HCV-related deaths }\end{array}$ \\
\hline & & & & ICER: \$AUS25,121 (\$AUS11,062-\$AUS39,036)/QALY \\
\hline
\end{tabular}

DAA direct acting agents, FO-3 METAVIR score, ICER incremental cost-effectiveness ratio, pegIFN/RBV peglyated interferon/ribavirin, QALY quality-adjusted life-years, SVR sustained virological response ${ }^{\text {a}}$ Calculated from data in published source 
Recently, at least three further modelling studies have evaluated the impact and cost-effectiveness of interferonfree DAAs in PWID. One study, based on UK data and integrating disease progression and transmission according to a previous model [55], projected that an increase in uptake of conventional treatment with a 58 \% SVR from 10 per 1000 PWID to 250 per 1000 PWID (among a modelled population of 4240 PWID with HCV prevalence of $25 \%$ ) would result in cost savings of $£ 5.4$ million between 2015 and 2027 after discounting at $3.5 \%$ per annum [58]. Using newer treatments with a $90 \%$ SVR was projected to increase the amount saved to $£ 36.3$ million, or £8.4 million after discounting [58].

In Australia, Hellard et al. modelled the expected healthcare costs and QALYs among newly HCV-infected PWID according to three scenarios: no treatment; 'early' treatment after initial infection; or 'late' treatment prior to developing compensated cirrhosis [72]. Compared with no treatment, early treatment and late treatment were associated with ICERs of AUS \$10,272/QALY (95 \% CI \$5689-13,690) and AUS \$5078/QALY (95 \% confidence interval \$2847-5295), respectively. Both of these values are well below the unofficial Australian willingness to pay threshold of AUS \$50,000/QALY. Early treatment was the most effective option in terms of QALYs gained, while late treatment was associated with a lower ICER because of a lower likelihood of re-infection in patients treated later in the course of infection due to the cessation of injection drug use. These researchers acknowledged that their analysis may have underestimated the cost-effectiveness of treatment for two reasons: it did not take into account any benefits from reduced infection transmission, and the costs of care for cirrhosis and liver cancer were based on minimum requirements [72].

Most recently, these authors have used a model that includes $\mathrm{HCV}$ transmission as well as disease progression and treatment, to estimate the treatment scale up and cost-effectiveness of reaching WHO targets of an $80 \%$ reduction in incidence and $65 \%$ reduction in HCV-related deaths by 2030, specifically among PWID [73]. According to this analysis, achieving the mortality target would require treatment to be scaled up to $30 / 1000$ injecting drug use-acquired infections per year among patients with advanced liver disease, while the incidence target required 59/1000 PWID to be treated each year. Prioritising treatment at this level only to PWID would achieve the mortality target with fewer treatment courses in total, but at the expense of a clinically unacceptable number of deaths among individuals with advanced disease. Hence, additional treatments (at the aforementioned rate, 30/1000/year) were required for patients with advanced liver disease for the first five years. Achieving both targets in this way was associated with an ICER of AUS \$25 121 (AUS\$11 062-AUS\$39 036) per QALY gained, below the unofficial cost-effectiveness threshold [73].

\section{Conclusion and recommendations}

The hepatitis $\mathrm{C}$ pandemic is a pressing public health threat. Strategic action at the policy level is urgently needed to increase access to $\mathrm{HCV}$ prevention, testing and treatment among PWID, the group at highest risk of $\mathrm{HCV}$ infection. Such action has the potential to substantially reduce the number of infected persons, along with the disease burden.

The World Health Organization has called for a global movement to create generalized access to HCV treatment [13], as have civil society organisations and other stakeholders [74]. They have further called for national and European strategies on $\mathrm{HCV}$ that include specific measures for PWID [28, 75, 76]. In 2014, the 67th World Health Assembly approved a resolution urging Member States to develop and implement coordinated multi-sectoral national strategies for preventing, diagnosing and treating viral hepatitis based on the local epidemiological context [77]. The first-ever WHO Global Health Sector Strategy on Viral Hepatitis (2016-2021) was adopted by the $69^{\text {th }}$ World Health Assembly on 28 May 2016 [78]. Aiming to contribute to the United Nations Sustainable Development Goals [79] and to eliminate viral hepatitis as a public health threat by 2030, the strategy highlights the opportunities available through investing in an essential, priority set of core interventions that include comprehensive integrated harm reduction services for PWID, linked with treatment [78]. This global strategy is complemented by a draft WHO European Region action plan for consideration by the Regional Committee in September 2016 [80]. Additionally, in the 2014-2016 EU Action Plan on HIV and Co-infections, the European Union has committed to work with Member States, neighbouring countries, civil society and the ECDC to implement risk and harm reduction measures for PWID and their partners for the prevention and treatment of HIV, co-infections and drug dependency in the community and prisons [81].

All policymakers responsible for health services in European Union countries should ensure that:

- National HCV action plans and strategies that include measures specifically to address HCV in PWID are developed and implemented across Europe;

- Evidence-based, comprehensive, multi-professional, community-led harm reduction and care/support programmes are provided and linked to $\mathrm{HCV}$ testing and treatment in the public and prison health systems;

- PWID have equitable access to effective HCV treatment, in line with published guidelines; 
- Measures are undertaken to reduce stigma and discrimination against PWID at the provider and institutional levels;

- HCV awareness and prevention campaigns are undertaken for healthcare providers (doctors, nurses and allied health professionals) and the PWID community; and

- The PWID community is involved in HCV service planning and implementation, with consideration given to peer support and PWID 'champions' initiatives.

\section{Abbreviations}

DAA, direct-acting antivirals; ECDC, European Centre for Disease Prevention and Control; HCV, hepatitis C virus; ICER, incremental cost-effectiveness ratio; NSP, needle and syringe programme; OST, opioid substitution therapy; Peg-IFN/RBV, pegylated interferon/ribavirin; PWID, people who inject drugs; QALY, quality adjusted life-years; SVR, sustained virological response; WHO, World Health Organization.

\section{Acknowledgements}

The authors thank the following individuals for their review and endorsement of this paper: Prof. Cathy Matheï (Assistant Professor, Academic Center for General Practice, Dept of Public Health and Primary Care, Free Clinic Antwerp, Belgium); Dr João Goulão (Portuguese National Coordinator on Drugs, Drug Addictions and the Harmful Use of Alcohol, Lisbon, Portugal); Dr Juan Antonio Pineda (Associate Professor, Infectious Diseases and Microbiology Unit, Hospital Universitario de Valme, Seville, Spain); Lisa Power, MBE (former Policy Director at Terrence Higgins Trust and Consultant at Potestatis.com, Cardiff, UK); Eberhard Schatz (Project Coordinator, Correlation Network and Foundation De Regenboog Groep [FRG], Amsterdam, Netherlands).

The authors acknowledge editorial support from Lee Baker (Interel, UK), funded by Gilead Sciences Europe Ltd.

\section{Authors' contributions}

All authors contributed equally via participation in the aforementioned meeting as well as providing input into the concept, outline and all drafts. All authors approved the final draft.

\section{Authors' information}

JD is Professor of Hepatology \& Gastroenterology at the School of Medicine, University of Dundee Ninewells Hospital and Medical School, Dundee, United Kingdom.

JVL is Editor-in-Chief of Hepatology, Medicine and Policy and Senior Researcher, the Centre for Health and Infectious Disease Research (CHIP), WHO Collaborating Centre on HIV and Viral Hepatitis Rigshospitalet, University of Copenhagen, Denmark.

HR is Managing Director, Center for Disease Analysis, Lafayette, Colorado, USA

\section{Competing interests}

This paper was born from discussions at a meeting of experts and patient advocates funded by Gilead Sciences Europe Ltd. The opinions expressed in this paper are the authors' own and the authors did not receive fees in respect of their roles in this publication. The contents of the paper do not necessarily reflect the view of Gilead Sciences Europe Ltd.

\section{Author details}

'Division of Molecular and Clinical Medicine, School of Medicine, University of Dundee, Ninewells Hospital, Dundee, UK. ${ }^{2}$ Centre for Health and Infectious Disease Research (CHIP) and WHO Collaborating Centre on HIV and Viral Hepatitis, Rigshospitalet, University of Copenhagen, Copenhagen, Denmark. ${ }^{3}$ Center for Disease Analysis, Louisville, Colorado, USA.

Received: 19 February 2016 Accepted: 20 June 2016 Published online: 30 June 2016

\section{References}

1. World Health Organization. Hepatitis C in the WHO European Region. WHO 2015. http://www.euro.who.int/_data/assets/pdf_file/0010/283357/factsheet-en-hep-c.pdf?ua=1. Accessed 2 Jun 2016.

2. Hatzakis A. Achieving WHO Recommendations for HCV in the European Union. Presented at the Polaris Symposium, Barcelona, Spain, April 132016. http://polarisobservatory.com/Barcelona2016/. Accessed 1 June 2016.

3. GBD 2013 Mortality and Causes of Death Collaborators. Global, regional, and national age-sex specific all-cause and cause-specific mortality for 240 causes of death, 1990-2013: a systematic analysis for the Global Burden of Disease Study 2013. Lancet. 2015;385:117-71.

4. Cramp ME, Rosenberg WM, Ryder SD1, Blach S, Parkes J. Modelling the impact of improving screening and treatment of chronic hepatitis $C$ virus infection on future hepatocellular carcinoma rates and liver-related mortality. BMC Gastroenterol. 2014;14:137.

5. Müllhaupt B, Bruggmann P, Bihl F, Blach S, Lavanchy D, Razavi H, et al. Modeling the health and economic burden of hepatitis $C$ virus in Switzerland. PLoS One. 2015;10:e0125214.

6. Sibley A, Han KH, Abourached A, Lesmana LA, Makara M, Jafri W, et al. The present and future disease burden of hepatitis $C$ virus infections with today's treatment paradigm - volume 3. J Viral Hepat. 2015;22 Suppl 4:21-41.

7. European Centre for Disease Prevention and Control. Hepatitis C surveillance in Europe - 2013. ECDC; 2015. http://ecdc.europa.eu/en/ publications/Publications/hepatitis-c-surveillance-in-europe-2013.pdf. Accessed 2 Jun 2016.

8. Nelson PK, Mathers BM, Cowie B, Hagan H, Des Jarlais D, Horyniak D, et al. Global epidemiology of hepatitis B and hepatitis $C$ in people who inject drugs: results of systematic reviews. Lancet. 2011;378:571-83.

9. European Monitoring Centre for Drugs and Drug Addiction. Hepatitis $C$ treatment for injecting drug users. EMCDDA, 2015. http://www.emcdda. europa.eu/attachements.cfm/att_212353_EN_EMCDDA_POD_2013_ Hep\%20C\%20treatment.pdf. Accessed 2 Jun 2016.

10. Wiessing L, Ferri M, Grady B, Kantzanou M, Sperle I, Cullen KJ, et al. Hepatitis $C$ virus infection epidemiology among people who inject drugs in Europe: a systematic review of data for scaling up treatment and prevention. PLoS One. 2014;9:e103345.

11. Rolls DA, Sacks-Davis R, Jenkinson R, McBryde E, Pattison P, Robins G, et al. Hepatitis $C$ transmission and treatment in contact networks of people who inject drugs. PLoS One. 2013;8:e78286.

12. Aspinall EJ, Corson S, Doyle JS, Grebely J, Hutchinson SJ, Dore GJ, et al. Treatment of hepatitis $C$ virus infection among people who are actively injecting drugs: a systematic review and meta-analysis. Clin Infect Dis. 2013;57 Suppl 2:S80-9.

13. World Health Organization. Guidelines for the screening, care and treatment of persons with hepatitis C infection. WHO. 2014. http://www.who.int/hiv/ pub/hepatitis/hepatitis-c-guidelines/en/. Accessed 2 Jun 2016.

14. European Centre for Disease Prevention and Control and European Monitoring Centre for Drugs and Drug Addiction. Prevention and control of infectious diseases among people who inject drugs. ECDC; 2011. http://www.emcdda. europa.eu/publications/ecdc-emcdda-guidance. Accessed 2 Jun 2016.

15. European Association for the Study of the Liver. EASL Recommendations on Treatment of Hepatitis C 2015. J Hepatol. 2015;63:199-236.

16. Grebely J, Robaeys G, Bruggmann P, Aghemo A, Backmund M, Bruneau J, et al. Recommendations for the management of hepatitis $C$ virus infection among people who inject drugs. Int J Drug Policy. 2015;26:1028-38.

17. Joint Action on HIV and co-infection prevention and harm reduction. www.HAREACT.eu, accessed 2 Jun 2016.

18. World Health Organization. Global policy report on the prevention and control of viral hepatitis in WHO Member States. WHO. 2013. http://apps.who.int/iris/ bitstream/10665/85397/1/9789241564632_eng.pdf. Accessed 2 Jun 2016.

19. Maticic M, Videcnik Zorman J, Gregorcic S, Schatz E, Lazarus JV. Are there national strategies, plans and guidelines for the treatment of hepatitis $C$ in people who inject drugs? A survey of 33 European countries. BMC Infect Dis. 2014;14 Suppl 6:S14.

20. Spina A, Eramova I, Lazarus JV. Policy responses to viral hepatitis B and C among people who inject drugs in Member States of the WHO European region: a sub-analysis of the WHO 2013 global hepatitis policy survey. BMC Infect Dis. 2014;14 Suppl 6:S15.

21. Lazarus JV, Sperle I, Maticic M, Wiessing L. A systematic review of hepatitis C virus treatment uptake among people who inject drugs in the European Region. BMC Infect Dis. 2014;14 Suppl 6:S16. 
22. Martin NK, Foster GR, Vilar J, Ryder S, Cramp ME, Gordon F, et al. HCV treatment rates and sustained viral response among people who inject drugs in seven UK sites: real world results and modelling of treatment impact. J Viral Hepat. 2015;22:399-408.

23. Larney S, Kopinski H, Beckwith CG, Zaller ND, Jarlais DD, Hagan H, et al. Incidence and prevalence of hepatitis $C$ in prisons and other closed settings: results of a systematic review and meta-analysis. Hepatology. 2013;58:1215-24.

24. Arain A, Robaeys G, Stöver H. Hepatitis C in European prisons: a call for an evidence-informed response. BMC Infect Dis. 2014;14 Suppl 6:S17.

25. Grebely J, Oser M, Taylor LE, Dore GJ. Breaking down the barriers to hepatitis $C$ virus ( $\mathrm{HCV}$ ) treatment among individuals with HCV/HIV coinfection: action required at the system, provider, and patient levels. J Infect Dis. 2013;207:S19-25.

26. Harris M, Rhodes T. Hepatitis C treatment access and uptake for people who inject drugs: review mapping the role of social factors. Harm Reduct J. 2013;10:7

27. Papatheodoridis GV, Tsochatzis E, Hardtke S, Wedemeyer H. Barriers to care and treatment for patients with chronic viral hepatitis in Europe: a systematic review. Liver Int. 2014;34:1452-63.

28. Papatheodoridis G, Thomas HC, Golna C, Bernardi M, Carballo M, Cornberg M, et al. Addressing barriers to the prevention, diagnosis and treatment of hepatitis B and C in the face of persisting fiscal constraints in Europe: report from a high level conference. J Viral Hepat. 2016;23 Suppl 1:1-12.

29. Alavi M, Micallef M, Fortier E, Dunlop AJ, Balcomb AC, Day CA, et al. Effect of treatment willingness on specialist assessment and treatment uptake for hepatitis C virus infection among people who use drugs: the ETHOS study. J Viral Hepat. 2015;22:914-25.

30. Treloar C, Rhodes T. The lived experience of hepatitis $C$ and its treatment among injecting drug users: qualitative synthesis. Qual Health Res. 2009:19:1321-34.

31. Jordan AE, Masson CL, Mateu-Gelabert P, McKnight C, Pepper N, Bouche K, et al. Perceptions of drug users regarding hepatitis $C$ screening and care: a qualitative study. Harm Reduct J. 2013;10:10.

32. National Institute for Health and Care Excellence. Drug misuse in over 16s: psychosocial interventions (CG51). National Institute for Health and Care Excellence. 2007. https://www.nice.org.uk/guidance/cg51. Accessed 2 Jun 2016.

33. Hutchinson SJ, Dillon JF, Fox R, McDonald SA, Innes HA, Weir A, et al. Expansion of HCV treatment access to people who have injected drugs through effective translation of research into public health policy: Scotland's experience. Int J Drug Policy. 2015;26:1041-9.

34. Hagan H, Pouget ER, Des Jarlais DC. A systematic review and meta-analysis of interventions to prevent hepatitis $C$ virus infection in people who inject drug. J Infect Dis. 2011;204:74-83.

35. Joint United Nations Programme on HIV/AIDS (UNAIDS). Services for people who inject drugs. Guidance note. UNAIDS, 2014. http://www.unaids.org/ sites/default/files/media_asset/2014_guidance_ servicesforpeoplewhoinjectdrugs_en.pdf. Accessed 2 Jun 2016.

36. Goldberg D, Hutchison S. Hepatitis C — setting standards in a journey towards the eradication of infection and disease as a serious health issue in the EU. 2014. http://www.hcvaction.org.uk/resource/hepatitis-c-settingstandards-journey-towards-eradication-infection-and-disease-serious. Accessed 2 Jun 2016.

37. Crawford S, Bath N. Peer support models for people with a history of injecting drug use undertaking assessment and treatment for hepatitis $C$ virus infection. Clin Infect Dis. 2013;57 Suppl 2:S75-9.

38. Grebely J, Knight E, Genoway KA, Viljoen M, Khara M, Elliott D, et al. Optimizing assessment and treatment for hepatitis $C$ virus infection in illicit drug users: a novel model incorporating multidisciplinary care and peer support. Eur J Gastroenterol Hepatol. 2010;22:270-7.

39. Keats J, Micallef M, Grebely J, Hazelwood S, Everingham H, Shrestha N, et al. Assessment and delivery of treatment for hepatitis $C$ virus infection in an opioid substitution treatment clinic with integrated peer-based support in Newcastle, Australia. Int J Drug Policy. 2015;26:999-1006.

40. Treloar C, Rance J, Bath N, Everingham H, Micallef M, Day C, et al. Evaluation of two community-controlled peer support services for assessment and treatment of hepatitis $C$ virus infection in opioid substitution treatment clinics: The ETHOS study, Australia. Int J Drug Policy. 2015;26:992-8.

41. WHO, UNODC, UNAIDS technical guide for countries to set targets for universal access to HIV prevention, treatment and care for injecting drug users - 2012 revision. WHO. 2013. http://www.who.int/hiv/pub/idu/targets_ universal_access/en/. Accessed 2 Jun 2016.
42. European Commission. Action Plan on Drugs 2013-2016 [2013/C 351/01]. Brussels, 2013. http://eur-lex.europa.eu/legal-content/EN/TXT/?uri=celex\% 3A52013XG1130(01). Accessed 2 Jun 2016.

43. Maticic M. A national multidisciplinary healthcare network for treatment of hepatitis C in people who inject drugs in Slovenia. BMC Infect Dis. 2014;14 Suppl 6:S6.

44. Stone S (ed). Global State of Harm Reduction 2014. Harm Reduction International. 2014. http://www.ihra.net/files/2015/02/16/GSHR2014.pdf. Accessed 2 Jun 2016.

45. Michel L, Lions C, Van Malderen S, Schitz J, Vanderplasschen W, Holm K, et al. Insufficient access to harm reduction measures in prisons in 5 countries (PRIDE Europe): a shared European public health concern. BMC Public Health. 2015;15:1093.

46. Moorman AC, Xing J, Ko S, Rupp LB, Xu F, Gordon SC, et al. Late diagnosis of hepatitis $C$ virus infection in the Chronic Hepatitis Cohort Study (CHeCS): Missed opportunities for intervention. Hepatology. 2015;61:1479-84.

47. European Association for the Study of the Liver and HIV in Europe. New consensus definition of late presentation for viral hepatitis. http://www.easl. eu/medias/files/HiE_late\%20present_Press\%20release_new_20150CT_final.pdf. Access 2 Jun 2016.

48. Aspinall EJ, Doyle JS, Corson S, Hellard ME, Hunt D, Goldberg D, et al. Targeted hepatitis $C$ antibody testing interventions: a systematic review and meta-analysis. Eur J Epidemiol. 2015;30:115-29.

49. Hahné SJ, Veldhuijzen IK, Wiessing L, Lim TA, Salminen M, Laar M. Infection with hepatitis $B$ and $C$ virus in Europe: a systematic review of prevalence and cost-effectiveness of screening. BMC Infect Dis. 2013;13:181.

50. Coats JT, Dillon JF. The effect of introducing point-of-care or dried blood spot analysis on the uptake of hepatitis $C$ virus testing in high-risk populations: A systematic review of the literature. Int J Drug Policy. 2015;26:1050-5.

51. Swain MG, Lai MY, Shiffman ML, Cooksley WG, Zeuzem S, Dieterich DT, et al. A sustained virologic response is durable in patients with chronic hepatitis $\mathrm{C}$ treated with peginterferon alfa-2a and ribavirin. Gastroenterology. 2010;139:1593-601.

52. van der Meer AJ, Veldt BJ, Feld JJ, Wedemeyer H, Dufour JF, Lammert F, et al. Association between sustained virological response and all-cause mortality among patients with chronic hepatitis $C$ and advanced hepatic fibrosis. JAMA. 2012;308:2584-93.

53. Holmes JA, Thompson AJ. Interferon-free combination therapies for the treatment of hepatitis C: current insights. Hepat Med. 2015;7:51-70.

54. Sievert W, Razavi H, Estes C, Thompson AJ, Zekry A, Roberts SK, et al. Enhanced antiviral treatment efficacy and uptake in preventing the rising burden of hepatitis C-related liver disease and costs in Australia. J Gastroenterol Hepatol. 2014;29 Suppl 1:1-9.

55. Martin NK, Hickman M, Hutchinson SJ, Goldberg DJ, Vickerman P. Combination interventions to prevent HCV transmission among people who inject drugs: modeling the impact of antiviral treatment, needle and syringe programs, and opiate substitution therapy. Clin Infect Dis. 2013;57 Suppl 2:S39-45.

56. Martin NK, Vickerman P, Grebely J, Hellard M, Hutchinson SJ, Lima VD, et al. Hepatitis $C$ virus treatment for prevention among people who inject drugs: Modeling treatment scale-up in the age of direct-acting antivirals. Hepatology. 2013;58:1598-609.

57. Alfaleh FZ, Nugrahini N, Matičič M, Tolmane I, Alzaabi M, Hajarizadeh B, et al. Strategies to manage hepatitis $C$ virus infection disease burden - volume 3. J Viral Hepat. 2015;22 Suppl 4:42-65.

58. Bennett H, McEwan P, Sugrue D, Kalsekar A, Yuan Y. Assessing the long-term impact of treating hepatitis c virus (HCV)-infected people who inject drugs in the UK and the relationship between treatment uptake and efficacy on future infections. PLoS One. 2015;10:e0125846.

59. Duberg AS, Blach S, Falconer K, Kåberg M, Razavi H, Aleman S. The future disease burden of hepatitis $C$ virus infection in Sweden and the impact of different treatment strategies. Scand J Gastroenterol. 2015;50:233-44.

60. Echevarria D, Gutfraind A, Boodram B, Major M, Del Valle S, Cotler SJ, et al. Mathematical modeling of hepatitis $C$ prevalence reduction with antiviral treatment scale-up in persons who inject drugs in metropolitan Chicago. PLoS One. 2015;10:e0135901.

61. Innes H, Goldberg D, Dillon J, Hutchinson SJ. Strategies for the treatment of Hepatitis $C$ in an era of interferon-free therapies: what public health outcomes do we value most? Gut. 2015;64:1800-9.

62. Martinez AD, Dimova R, Marks KM, Beeder AB, Zeremski M, Kreek MJ, et al. Integrated internist - addiction medicine - hepatology model for hepatitis C 
management for individuals on methadone maintenance. J Viral Hepat. 2012;19:47-54.

63. Alavi M, Grebely J, Micallef M, Dunlop AJ, Balcomb AC, Day CA, et al. Assessment and treatment of hepatitis $C$ virus infection among people who inject drugs in the opioid substitution setting: ETHOS study. Clin Infect Dis. 2013;57 Suppl 2:S62-9.

64. Wade AJ, Macdonald AM, Doyle JS, Gordon A, Roberts SK, Thompson AJ, et al. The cascade of care for an Australian community-cased hepatitis $\mathrm{C}$ treatment service. PLoS One. 2015;10:e0142770.

65. McDonald SA, Innes HA, Hayes PC, Dillon JF, Mills PR, Goldberg DJ, et al. What is the impact of a country-wide scale-up in antiviral therapy on the characteristics and sustained viral response rates of patients treated for hepatitis C? J Hepatol. 2015;62:262-8.

66. Cure S, Guerra I, Dusheiko G. Cost-effectiveness of sofosbuvir for the treatment of chronic hepatitis C-infected patients. J Viral Hepat. 2015;22:882-9.

67. Gissel C, Götz G, Mahlich J, Repp H. Cost-effectiveness of Interferon-free therapy for Hepatitis $C$ in Germany-an application of the efficiency frontier approach. BMC Infect Dis. 2015;15:297.

68. Kim DD, Hutton DW, Raouf AA, Salama M, Hablas A, Seifeldin IA, et al. Cost-effectiveness model for hepatitis $C$ screening and treatment: Implications for Egypt and other countries with high prevalence. Glob Public Health. 2015:10:296-317.

69. Leleu H, Blachier M, Rosa I. Cost-effectiveness of sofosbuvir in the treatment of patients with hepatitis C. J Viral Hepat. 2015;22:376-83.

70. Martin NK, Vickerman P, Miners A, Foster GR, Hutchinson SJ, Goldberg DJ, et al. Cost-effectiveness of hepatitis $C$ virus antiviral treatment for injection drug user populations. Hepatology. 2012;55:49-57.

71. Visconti AJ, Doyle JS, Weir A, Shiell AM, Hellard ME. Assessing the costeffectiveness of treating chronic hepatitis $C$ virus in people who inject drugs in Australia. J Gastroenterol Hepatol. 2013;28:707-16.

72. Hellard M, Thompson A, Scott N, Iser D, Doyle JS. Cost-effectiveness of treating chronic hepatitis $C$ virus with direct-acting antivirals in people who inject drugs in Australia. J Gastroenterol Hepatol. 2016;31:872-82.

73. Scott N, McBryde ES, Thompson A, Doyle JS, Hellard ME. Treatment scale-up to achieve global HCV incidence and mortality elimination targets: a cost-effectiveness model. Gut. 2016. doi: 10.1136/gutjnl-2016-311504. [Epub ahead of print]

74. NoHep website. www.nohep.org. Accessed 2 Jun 2016

75. Hepatitis C Coalition. Defuse hepatitis $C$, the viral time bomb: test and treat hepatitis C Position Paper for the 67th World Health Assembly, May 19-24, 2014. http:/www.hepcoalition.org/advocate/advocacy-tools/article/defusehepatitis-c-the-viral-time. Accessed 2 Jun 2016.

76. Hepatitis C Initiative. Manifesto - Berlin Declaration. 2014. www.hepatitis-cinitiative.eu. Accessed 2 Ju 2016.

77. World Health Assembly. Resolution on hepatitis. 67th World Health Assembly, 24 May 2014. http://www.who.int/mediacentre/news/releases/ 2014/WHA-20140522/en/. Accessed 2 Jun 2016.

78. World Health Organization. Draft global health sector strategy on viral hepatitis, 2016-2021 - the first of its kind. WHO. 2015. http://www.who.int/ hiv/strategy2016-2021/en/. Accessed 2 Jun 2015.

79. United Nations. The Global Goals for Sustainable Development, 2015. UN. 20155. www.un.org/sustainabledevelopment/sustainable-developmentgoals). Accessed 2 Jun 2016.

80. World Health Organization Europe. Action plan for the health sector response to viral hepatitis in the WHO European Region (Draft 3.0). http:// www.euro.who.int/en/health-topics/communicable-diseases/hepatitis/news/ news/2016/05/consultation-for-action-plans-on-hiv-and-viral-hepatitis. Accessed 2 Jun 2016.

81. European Commission. Action Plan on HIV/AIDS in the EU and neighbouring countries: 2014-2016 [SWD(2014) 106 final]. Brussels, 2014. http://ec.europa.eu/ health/sti_prevention/docs/ec_hiv_actionplan_2014_en.pdf. Accessed 11 Feb 2016.

\section{Submit your next manuscript to BioMed Central and we will help you at every step:}

- We accept pre-submission inquiries

- Our selector tool helps you to find the most relevant journal

- We provide round the clock customer support

- Convenient online submission

- Thorough peer review

- Inclusion in PubMed and all major indexing services

- Maximum visibility for your research

Submit your manuscript at www.biomedcentral.com/submit

) Biomed Central 